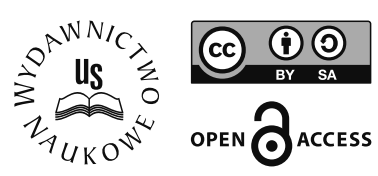

\title{
Jarosław Drozd
}

Institute of History

University of Gdańsk

jaroslaw.drozd@ug.edu.pl

ORCID: 0000-0001-5577-5696

\section{Register Files of The State Enterprise and the Joint Stock Company "Żegluga Polska" in Gdynia as a Source in Research on the Polish Merchant Navy under the Second Polish Republic}

Keywords: Gdynia, shipping, Polish merchant navy, Second Polish Republic, interwar period, state archives

The Companies Register files found in the fonds of the Municipal Court in Gdynia constitute an exceptionally valuable source for research on the history of the Polish Merchant Navy and the economic history of the Second Polish Republic ${ }^{1}$. In 2003, they were edited and prepared for release (by the author of this article), but, despite the passage of years, they are still used in research only by a narrow group of historians. All the greater the pity that the fonds contains register files of Polish shipping companies, which should be used as source material for research on issues related to the history of maritime economy in the Second Polish Republic. In this article, the records of the Companies Register were used to describe the circumstances of the establishment, the organisation, the activity, the fleet, and the operational and financial results of Przedsiębiorstwo Państwowe “Żegluga Polska” [lit. State-owned Enterprise

1 The Companies Register was established in the Second Polish Republic under the decree of the Chief of State of 7 February 1919 and the regulation of the Minister of Justice of 22 April 1919 on the Companies Register. It was divided into three sections. General partnerships and limited partnerships were entered in RHA [Companies Register A], data on limited liability companies and joint-stock companies were entered in RHB [Companies Register B], and information on companies with foreign investment capital was entered in RHC [Companies Register C]. The Register was kept in the form of books annexed with register files. The register files of the Municipal Court in Gdynia were handed over to the State Archives in Gdańsk on 14 September 1982. The fonds was given the reference code APG 1845 and was deposited in the repository of the Department in Gdynia. After the Gdynia Department had been transformed into a Branch Division, the fonds received a new reference code (APG OG 149), and once it had been edited and prepared for release (in 2003), it was officially put into "scientific circulation". 
"Polish Shipping"], Poland's oldest and largest shipping company, which transformed from a pioneering state-owned business into an efficient joint-stock company. Register files of Przedsiębiorstwo Państwowe "Żegluga Polska" (one volume from the years 1926-1932), in comparison with the register records of "Żegluga Polska" SA (two volumes from the years 1932-1939), contain relatively sparse source materials. However, they are of exceptional value, if only because they regard the pioneering period in the development of the Polish Merchant Navy. On the other hand, the documents of "Żegluga Polska" SA (mainly reports on the company's activities from the years 19321938) constitute a unique and extremely detailed historical source, rich in operational and financial data, which can be used to supplement information found in the issues of Rocznik Rady Interesantów Portu Gdyńskiego [Yearbook of the Port of Gdynia Stakeholder Council], Rocznik Statystyczny Gdyni [Gdynia Statistical Yearbook], or Rocznik Morski i Kolonialny [Maritime and Colonial Yearbook].

Przedsiębiorstwo Państwowe "Żegluga Polska" was established in 1926 under the State-owned Enterprises Act. The impetus for this undertaking was provided by the Ministry of Industry and Trade, which, in the autumn of 1927, bought five "Wilno" type collier ships in France. They arrived in Gdynia in the first days of January 1928 and were soon loaded in Gdańsk with wood destined for the ports of Western Europe (with time, of course, they also started carrying coal). At the beginning of 1928, the fleet of "Żegluga Polska" consisted of nine ships, including two passenger ships. In the same year, another two cargo ships and two smaller passenger ships were ordered in England. It was a time when Polish society was becoming more and more interested in maritime affairs. An important role in popularising the Polish Merchant Navy was played by the company's inconspicuous coastal passenger ships, whose decks were filled with more and more tourists every season. "Work on land, rest at sea" - this simple advertising catchphrase, probably coined by the managing director of "Żegluga Polska", Engineer Julian Rummel, won thousands of supporters and enthusiasts in the country. Since the condition of the ports in Hel and Jastarnia left much to be desired, two new ships, SS "Jadwiga" and SS "Wanda", were launched to provide liner services on the routes to these destinations. Solemn blessing of the ships took place in June 1928 in the presence of Marshal Józef Piłsudski, who visited Gdynia for the first time, accompanied by his two daughters (the godmothers of the two vessels). At the same time, a small paddle steamer SS "Hanka" was launched on this route (her godmother was Engineer Eugeniusz Kwiatkowski’s daughter). The company's development program, adopted by the Administrative Council of "Żegluga Polska" in 1929, provided for the establishment of liner services, without neglecting tramp services. The company's first liner services were to Riga, Tallinn and Helsinki. After ten years of operation, "Żegluga Polska” SA already served eleven routes with constant cargo flows, connecting Gdynia and Gdańsk with Antwerp, Rotterdam, Hamburg, ports of Italy, Sweden, Finland, 
Latvia, Estonia, and the Middle East. Before the outbreak of World War II, "Żegluga Polska" SA had the largest fleet out of all the Polish shipping companies, with 16 ships (not counting coastal shipping and tugs) with a total Gross Register Tonnage (GRT) of 25,073 and was a showpiece of the Polish Merchant Navy.

At the request of the managing director, Engineer J. Rummel, on 8 January 1927, Państwowe Przedsiębiorstwo "Żegluga Polska" was entered in the Companies Register of the Municipal Court in Gdynia (under reference number RHB 23) ${ }^{2}$. The scope of business activities specified in the compan's statute included "the transport of goods and travellers by sea and all related activities". This entry was supplemented on 30 May 1928 with the following: "the performance of sea transport services with particular emphasis on the needs of the State and domestic industry and trade, transport of people and cargo and performance of related financial and commercial operations such as selling ship tickets, taking goods into storage, granting loans, etc."3. Engineer J. Rummel, an excellent organiser, without whom the development of "Żegluga Polska" would have been impossible, had remained in the position of managing director until the firm was transformed into a joint-stock company. The only change in managerial personnel took place on 14 May 1930 when, pursuant to a resolution of the Administrative Council, the then Minister of Industry and Trade, Engineer E. Kwiatkowski dismissed Kazimierz Rothert (head of the Freight Department) from the position of deputy managing director and appointed Hugo Teofil Pistel in his place 4 .

The circumstances of transforming Przedsiębiorstwo Państwowe "Żegluga Polska" in Gdynia into a joint-stock company are well documented in the register files. The transformation was initiated by the Minister of Industry and Trade, Dr. Ferdynand Zarzycki. On the basis of the resolution of the Council of Ministers of 27 January 1932, he submitted an appropriate bill to the Sejm (Parliament) of the Republic of Poland. In the recitals to the proposal, the minister wrote that the reason for this decision was to create conditions in which private capital could be invested in the state-owned enterprise. The reasons for choosing the new organisational form for the company were

2 State Archives in Gdańsk, Gdynia Branch (Archiwum Państwowe w Gdańsku Oddział w Gdyni, hereinafter: APG OG), the Municipal Court in Gdynia (Sąd Grodzki w Gdyni, hereinafter: SGG), 149/416, Postanowienie o wpisie do rejestru handlowego $z 2$ marca 1927 r., 1, 5 [Decision on entry in the Companies Register of 2 March 1927, 1, 5]. Engineer J. Rummel referred to the nomination issued on 10 November 1926, by the Minister of Industry and Trade, Engineer E. Kwiatkowski and a letter of authorisation of 29 December 1926, issued by the Chair of the Administrative Council, Dr. Cyryl Ratajski.

3 Ibidem, 149/416, Wniosek Państwowego Przedsiębiorstwa "Żegluga Polska” do SGG z 30 maja 1928 r. o uzupetnienie wpisu do rejestru handlowego, 11. [Application of Przedsiębiorstwo Państwowe "Żegluga Polska" to SGG of 30 May 301928 for supplementing the entry in the Companies Register, 11].

4 Ibidem, Uzupelnienie wniosku do rejestru handlowego Sąu Grodzkiego w Gdyni z 21 sierpnia 1930 r., 18 [Supplement to the application to the Companies Register of the Municipal Court in Gdynia of $21 \mathrm{Au}$ gust 1930, 18]. See also: Ibidem, Postanowienie o wpisie do rejestru handlowego z 8 października 1930 r., 27 [Decision of 8 October 1930 on Entry in the Companies Register, 27]. 
based on the conviction of the then Government that the pioneering period in the company's activity had come to an end and that appropriate conditions had been created for the company to be run in cooperation with local government or private capital. In July 1932, the Ministry of Industry and Trade announced the end of the liquidation of the enterprise operating under the old rules and its "expiry". The enterprise was removed from the Company Register on 31 August $1932^{6}$. Of great importance here is the notarial deed of 18 July 1932, preserved in the first volume of the company's register records. Citing the Act of 17 March 1932, on the transformation of a state-owned enterprise into a joint-stock company (Official Journal of the Republic of Poland No. 32, item 339) and the Order of the Ministry of Industry and Trade of 9 July 1932, with the approval of the Ministry of Treasury, the director of the Maritime Department at the Ministry of Industry and Trade, Dr. Feliks Hilchen, issued a consent to establish a joint-stock company by the name "Żegluga Polska" with a capital of PLN 8 million? The managing director of the company was Feliks Kollat, director of the "Polish-British Ship Society" in Gdynia, who was also a member of the management board of that latter institution, which "was not considered a competitive enterprise". Feliks Kollat remained in his position until the outbreak of World War II, also serving as president of the Polish Shipowners' Union and honorary consul of Japan. Upon his motion of

5 Ibidem, Wniosek ministra przemystu $i$ handlu z 15 lipca 1932 r. o przekształcenie przedsiębiorstwa państwowego Żegluga Polska" na spótkę akcyjna, 37 [Motion of the Minister of Industry and Trade of 15 July 1932 to transform Przedsiębiorstwo Państwowe "Żegluga Polska" into a joint-stock company, 37]. The files include the opening balance sheet of "Żegluga Polska" SA as of 1 April 1932, the balance sheet of Przedsiębiorstwo Państwowe "Żegluga Polska" for the year 1931/32 and the liquidation balance sheet of Przedsiębiorstwo Państwowe "Żegluga Polska" as of 31 March 1932.

6 Ibidem, Postanowienie o wykreśleniu z rejestru handlowego z 31 sierpnia 1932 r., 39. [Decision of 31 August 1932 on removal from the Companies Register, 39].

7 APG OG, SGG, 149/604, Akt notarialny z 18 lipca 1932 r. (rep. 961/32) zawarty przed Atanazym Zalewskim, zastępca notariusza H. Ewerta-Krzemieniewskiego w Gdyni), 21nn. [Notarial deed of 18 July 1932 (ref. no. 961/32) concluded before Atanazy Zalewski, deputy of notary public H. Ewert-Krzemieniewski in Gdynia), 21 ff.] See also: Ibidem, Postanowienie MPiH z 18 czerwca 1934 r. w sprawie zezwolenia "Żegludze Polskiej” S.A. w Gdyni na podwyższenie kapitału zakładowego, 112. [Decision of the Ministry of Industry and Trade of June 18, 1934 authorising "Żegluga Polska" SA in Gdynia to increase its share capital, 112]. Ibidem, Potwierdzenie wpisu do rejestru handlowego z 31 października 1934 r., 122 [Confirmation of entry in the company register of 31 October 1934, 122]. The non-cash contribution to the company's capital were the tugboats: "Ursus", “Tur", "Bizon" and "Żubr". The State Treasury owned 40,000 registered IPO shares and 1,500 FPO shares. The company's share capital was increased to PLN 8,300,000 upon the motion of its authorities of 3 August 1934, with funds raised in a follow-on public offering of 1,500 registered shares with a nominal value of PLN 200 each (APG OG, SGG, 149/605, Postanowienie MPiH w sprawie zatwierdzenia zmiany statutu S.A. pod nazwa "Żegluga Polska" z 29 lipca 1939 r., 219-222 [Decision of the Ministry of Industry and Trade of 29 July 1939 on the approval of the change of the statute of the joint-stock company by the name "Żegluga Polska", 219-222. At the general meeting of shareholders held on 7 July 1939, in Gdynia, the share capital was increased to PLN 15,000,000.

8 APG OG, SGG, 149/604, Protokół z posiedzenia Rady Nadzorczej "Żegluga Polska" S.A. z 18 lipca 1932 r., 25n [Minutes from the meeting of the Supervisory Board of "Żegluga Polska" SA of 18 July 1932, 25f]. 
26 June 1936, the Supervisory Board handed over the functions of the deputy managing director to the then procurator, Dr. Stanisław Darski, who also remained in his position until the end of the Second Polish Republic?.

"Żegluga Polska" SA was entered into the Companies Register of the Municipal Court in Gdynia (under ref. no. RHB 206) on 3 November $1932^{10}$. Its statute, preserved in its entirety in the first volume of the register files, was approved under the Decision of the Ministry of Industry and Trade on 13 July $1932^{11}$. From then on, the company's most important tasks included: "transporting people and goods by sea, on its own ships and leased vessels, and by land; carrying out all financial and commercial operations related to this purpose and running the company's own industrial enterprises or purchasing and selling syndicated shares in other enterprises. In particular, the scope of the company's activities includes: sale of ship, train and other tickets; taking goods into storage; granting loans for goods accepted for storage and transport; insurance of freight accepted for storage and transport; arranging all kinds of forwarding, brokerage and other activities related to the transport and storage of goods; building and maintaining the company's own marinas and warehouses; transportation of passengers, luggage and goods in mixed and land-sea transport based on direct shipping documents ${ }^{12}$.

In the first operational year (from 1 April 1932 to 31 December 1933), "Żegluga Polska" SA offered liner services operated by three ships. Two of them (SS "Cieszyn" and SS "Śląsk") sailed every fortnight from Gdynia/Gdańsk to Tallinn and Helsinki (occasionally calling at the port of Kotka) as well as to Rotterdam and Antwerp. The third steamer (SS “Tczew") first ran on a biweekly schedule (from 1 April 1932 to 1 September 1933) to Rotterdam, but was then transferred to the route to Antwerp, and was replaced on the route to Rotterdam by SS "Chorzów"13. In 1934, "Żegluga Polska" SA already operated six liner services with its own ships ("Śląsk", "Cieszyn", "Chorzów" and "Tczew") and with chartered vessels. Two journeys were also made by the tramp ships SS "Wilno" and SS "Katowice". New liner services were launched connecting Gdynia/Gdańsk with Hamburg (service operating from 15 February 1934,

9 APG OG, SGG, 149/605, Wniosek z 12 września 1936 r. o wpisanie do rejestru handlowego dr S. Darskiego, 28n. [Motion of 12 September 1936 to enter Dr. S. Darski into the Companies Register, 28f.].

10 APG OG, SGG, 149/604, Postanowienie o wpisie do rejestru handlowego z 19 lipca 1932 r., 36n, 41 [Decision of 19 July 1932 on entry in the Companies Register, 36n, 41].

11 Ibidem, Odpis postanowienia ministra przemystu i handlu $z 13$ lipca 1932 r., 3 [Copy of the Decision of the Minister of Industry and Trade of 13 July 1932, 3]. See also: Ibidem, Wniosek o wpis do rejestru handlowego z 18 lipca 1932 r., 1 [Application of 18 July 1932 for entry in the Companies Register, 1].

12 Ibidem, Statut Spótki Akcyjnej "Żegluga Polska” w Gdyni, 4-12 [Statute of the Joint Stock Company "Żegluga Polska" in Gdynia, 4-12]. The company took over from the liquidated state-owned enterprise, a fleet consisting of ten freight vessels with a tonnage of 20,459.19 GRT, two freight-and-passenger ships (2804.24 GRT), and five passenger ships (1,763.89 GRT), 25,027.32 GRT in total.

13 APG OG, SGG 149/604, Sprawozdanie zarzadu S.A. "Żegluga Polska" za rok operacyjny 1932/33, 81 [Report of the Board of "Żegluga Polska" S.A. for the operating year 1932/33, 81]. 
with SS "Tczew" running every 16-17 days) and the ports of eastern Sweden - Stockholm and Norrköping (service operated every three weeks, from 7 December 1934, by the chartered vessel SS "Haneström V"). The import traffic of "Żegluga Polska" SA was fully satisfactory, in contrast to its export turnover, which is why the company started to pay more attention to transshipment cargo. Despite the fact that the carrier concluded an agreement with German shipping companies, the turnover on the Hamburg line did not increase. By contrast, transport traffic on the route to Antwerp was becoming better and better, also owing to a large share of transshipment traffic ${ }^{14}$.

Table 1. Operating results of "Żegluga Polska" SA's liner services in 1934

\begin{tabular}{|l|c|c|c|c|}
\hline \multicolumn{1}{|c|}{ Destination: } & Export & Import & Transshipment & Total \\
\hline Rotterdam & $29,392$. & 61,220 & 2,031 & 92,645 \\
\hline Antwerp & 29,548 & 17,163 & 3,181 & 49,892 \\
\hline Finland & 16,074 & 10,008 & 5,692 & 31,774 \\
\hline Hamburg & 7,289 & 6,982 & - & 14,271 \\
\hline Sweden & 821 & 165 & - & 986 \\
\hline TOTAL & 83,124 & 95,538 & 10,904 & 189,568 \\
\hline
\end{tabular}

Source: APG OG, SGG, 149/604, 150; APG OG 149/605, $10 \mathrm{ff}$.

In 1935, in addition to the previous links, liner services to Riga and Klaipeda and the ports of the Levant were launched. They were operated by six of the company's own ships ("Śląsk”, "Cieszyn”, "Chorzów”, "Tczew”, and two new ships, SS "Puck” and SS "Hel") and by chartered vessels. The latter were to be gradually replaced with the company's own tonnage. This mainly concerned the ships sailing along the route to the ports of the Levant, SS "Lewant" and SS "Sarmacja". During the operation of these ships, it turned out that the first of them, in particular, was fully suited to the needs of this route, so the company started negotiations to purchase this vessel. The new liner service to Riga and Klaipeda (Eastern Baltic) was unprofitable, but it was believed to have a potential for development. In 1935, SS "Wisła" was launched to maintain a regular connection with the ports of South America. Until 1937, the ship made a total of five voyages to ports in Argentina and Brazil, and the route was operated jointly with the shipping company "Gdynia-Ameryka, Linie Żeglugowe” [Gdynia-America, Shipping Lines], which deployed SS "Pułaski” on this route.

14 Ibidem, Sprawozdanie zarządu z działalności spółki za rok 1934, 150n [Report of the Board on the company's activities for the year 1934, 150f]. In December 1934, SS “Cieszyn”, which operated on the route to Tallinn/Helsinki, as an exception called to Leningrad for a load of apples. 
Table 2. Operating results of "Żegluga Polska" SA's liner services in 1935

\begin{tabular}{|l|c|c|c|c|}
\hline \multicolumn{1}{|c|}{ Destination: } & Export & Import & Transshipment & Total \\
\hline Rotterdam & 36,661 & 38,955 & 1,031 & 76,647 \\
\hline Antwerp & 36,221 & 24,220 & 1,355 & 61,796 \\
\hline Finland & 21,726 & 7,596 & 2,366 & 31,688 \\
\hline Hamburg & 6,239 & 10,384 & - & 16,623 \\
\hline Sweden & 11,334 & 6,158 & - & 17,492 \\
\hline Eastern Baltic & 947 & 1,166 & - & 2,113 \\
\hline Ports of the Levant & 10,413 & 4,868 & - & 15,281 \\
\hline TOTAL & 123,541 & 93,347 & 4,752 & 221,640 \\
\hline
\end{tabular}

Source: APG OG, SGG, 149/605, $10 \mathrm{ff}$.

In 1936, “Żegluga Polska” SA launched its eighth liner service (to Gothenburg and ports in south-western Sweden), and the fleet was supplemented with SS "Lewant", bought from the Swedish shipping company "Svenska Orient Linien"15. In 1937, another service was launched (to the ports of Turku-Åbo in western Finland). At that time, the company provided liner services along nine routes: to Antwerp ("Hel" and "Śląsk"), Rotterdam (“Chorzów” and "Puck”), Hamburg (“Tczew”), Tallinn-KotkaVipuri-Helsinki (“Cieszyn”), Riga-Liepaja-Klaipeda (SS “Anna Greta”, on charter), Stockholm-Range (SS "Kjörrefjord”, on charter), Malmö-Gothenburg (SS "Blenda", on charter), ports of the Levant ("Lewant" and SS "Lechistan"), and Turku-Åbo (SS "Bro", on charter) ${ }^{16}$.

Table 3. Operating results of "Żegluga Polska" SA's liner services in 1936

\begin{tabular}{|l|c|c|c|c|}
\hline \multicolumn{1}{|c|}{ Destination: } & Export & Import & Transshipment & Total \\
\hline Antwerp & 50,603 & 32,309 & 61 & 82,973 \\
\hline Rotterdam & 52,706 & 38,784 & 64 & 91,554 \\
\hline Finland & 24,353 & 3,999 & 2,495 & 30,847 \\
\hline Hamburg & 7,239 & 10,873 & 57 & 18,169 \\
\hline Eastern Sweden & 16,315 & 7,018 & 48 & 23,381 \\
\hline Western Sweden & 7,755 & 4,190 & 259 & 12,204 \\
\hline Eastern Baltic & 1,455 & 3,193 & 4,555 & 9,204 \\
\hline Ports of the Levant & 26,772 & 11,141 & 7,886 & 45,749 \\
\hline TOTAL & 187,148 & 111,507 & 15,426 & 314,081 \\
\hline
\end{tabular}

Source: APG 0G, SGG, 149/605, 58 .

The last register file data on the development of “Żegluga Polska” SA's liner services come from 31 December 1938. At that time, the company expanded the scope of its

15 Ibidem, Sprawozdanie zarządu za rok 1936, 57n [Report of the Board for 1936, 57f.].

16 Ibidem, Sprawozdanie zarząu spółki za rok 1937, 112 [Report of the Company Board for 1937, 112]. 
activity by launching liner services on routes to Genoa, Livorno and ports of Sicily (the Italian line) and to Ghent (via Hamburg). The company now operated a total of eleven routes: to Antwerp ("Cieszyn", "Poznań"), Rotterdam ("Chorzów" and "Wilno"), Hamburg and Ghent (MS "Oksywie"), Tallinn- Kotka-Viipuri-Helsinki ("Śląsk"), Turku -Åbo-Mantyluoto-Vaasa (“Śląsk”), Riga-Liepaja-Klaipeda (SS “Alfa”, on charter), Stockholm (MS "Rozewie"), Malmö-Gothenburg ("Blenda", on charter), ports of the Levant ("Lewant" and "Lechistan"), Genoa-Livorno-Napoli-ports of Sicily ("Katowice", "Puck", and "Hel") 17.

Table 4. Comparative analysis of receipts from regular freight transport services in the years 1936-1938

\begin{tabular}{|c|c|c|c|c|c|c|c|}
\hline Line & Year & Export & Import & Transshipment & $\begin{array}{c}\text { Between } \\
\text { ports }\end{array}$ & Total & $\begin{array}{l}\text { Increase/ } \\
\text { decrease }\end{array}$ \\
\hline \multirow[t]{3}{*}{ Antwerp } & 1938 & 56,658 & 43,010 & - & - & 99,668 & $-5,8 \%$ \\
\hline & 1937 & 58,852 & 47,012 & - & - & 105,864 & $28 \%$ \\
\hline & 1936 & 50,603 & 32,309 & 61 & - & 82,973 & n.d. \\
\hline \multirow[t]{3}{*}{ Rotterdam } & 1938 & 56,853 & 45,901 & - & - & 102,754 & $-12,7 \%$ \\
\hline & 1937 & 68,490 & 49,188 & 5 & - & 117,672 & $29 \%$ \\
\hline & 1936 & 52,706 & 38,784 & 64 & - & 91,554 & n.d. \\
\hline \multirow[t]{3}{*}{ Hamburg } & 1938 & 7,077 & 10,245 & - & - & 17,322 & $-2,8 \%$ \\
\hline & 1937 & 6,814 & 11,005 & 10 & - & 17,829 & $-2 \%$ \\
\hline & 1936 & 7,239 & 10,873 & 57 & - & 18,169 & n.d. \\
\hline \multirow{3}{*}{$\begin{array}{l}\text { Southern Finland } \\
\text { and Tallinn }\end{array}$} & 1938 & 28,820 & 9,114 & 2,557 & 1,151 & 41,642 & $-1,8 \%$ \\
\hline & 1937 & 27,940 & 12,405 & 1,243 & 843 & 42,431 & $38 \%$ \\
\hline & 1936 & 24,353 & 3,999 & 2,247 & 248 & 30,847 & n.d. \\
\hline \multirow[t]{3}{*}{ East Baltic (Riga) } & 1938 & 2,144 & 1,179 & 5,573 & 76 & 8,972 & $-15,6 \%$ \\
\hline & 1937 & 1,205 & 1,769 & 7,628 & 33 & 10,635 & $16 \%$ \\
\hline & 1936 & 1,455 & 3,193 & 4,545 & 11 & 9,204 & n.d. \\
\hline \multirow{3}{*}{$\begin{array}{l}\text { Eastern Sweden } \\
\text { (Stockholm) }\end{array}$} & 1938 & 17,990 & 10,554 & 346 & 241 & 29,131 & $6,6 \%$ \\
\hline & 1937 & 15,803 & 11,478 & 59 & - & 27,340 & $17 \%$ \\
\hline & 1936 & 16,315 & 7,018 & 48 & - & 23,381 & n.d. \\
\hline \multirow{3}{*}{$\begin{array}{l}\text { Western Sweden } \\
\text { (Malmö) }\end{array}$} & 1938 & 9,971 & 4,597 & 125 & - & 14,693 & $-6,9 \%$ \\
\hline & 1937 & 10,618 & 5,140 & 4 & 23 & 15,785 & $30 \%$ \\
\hline & 1936 & 7,755 & 4,190 & 259 & - & 12,204 & n.d. \\
\hline \multirow[t]{3}{*}{ Levant } & 1938 & 40,470 & 22,405 & 385 & 20,792 & 84,053 & $26,2 \%$ \\
\hline & 1937 & 32,223 & 15,412 & 425 & 12,756 & 60,816 & $33 \%$ \\
\hline & 1936 & 26,722 & 11,141 & 919 & 6,967 & 45,749 & \\
\hline
\end{tabular}

17 Ibidem, Sprawozdanie zarzadu za rok 1938, 57n [Report of the Board for 1936, 57f]. 


\begin{tabular}{|l|c|c|c|c|c|c|c|}
\hline \multicolumn{1}{|c|}{ Line } & Year & Export & Import & Transshipment & $\begin{array}{c}\text { Between } \\
\text { ports }\end{array}$ & Total & $\begin{array}{c}\text { Increase/ } \\
\text { decrease }\end{array}$ \\
\hline $\begin{array}{l}\text { Western Finland } \\
\text { (Turku) }\end{array}$ & 1938 & 18,293 & 11,645 & 343 & - & 30,281 & $29,7 \%$ \\
\cline { 2 - 9 } & 1937 & 16,609 & 6,482 & 250 & - & 23,341 & $100 \%$ \\
\cline { 2 - 9 } & 1936 & - & - & - & - & - & - \\
\hline \multirow{4}{*}{ Ghent } & 1938 & 2,362 & 598 & - & 84 & 3,044 & $100 \%$ \\
\cline { 2 - 9 } & 1937 & - & - & - & - & - & - \\
\cline { 2 - 9 } & 1936 & - & - & - & - & - & - \\
\hline \multirow{4}{*}{ Genoa } & 1938 & 3,709 & 1,483 & 77 & - & 5,269 & $100 \%$ \\
\cline { 2 - 9 } & 1937 & - & - & - & - & - & - \\
\cline { 2 - 9 } & 1936 & - & - & - & - & - & - \\
\hline \multirow{4}{*}{ Total } & 1938 & 244,347 & 160,732 & 9,406 & 22,344 & 436,829 & $4 \%$ \\
\cline { 2 - 9 } & 1937 & 238,554 & 159,880 & 9,624 & 13,655 & 421,713 & $34 \%$ \\
\cline { 2 - 9 } & 1936 & 187,148 & 111,507 & 8,200 & 7,226 & 314,081 & n.d. \\
\hline
\end{tabular}

Source: APG 0G, SGG, 149/605, 112f, 178.

The report on the activity of "Żegluga Polska" SA in Gdynia in the first operating year, which covered the period from 1 April 1932 to 31 December 1933, confirms that tramp shipping services (with no fixed routing or itinerary) were provided in a market characterised by falling freight rates and decreasing coal exports. Despite these difficulties, the company's ships were in operation throughout 1932, except for short periods when no suitable employment could be found for the larger vessels (SS "Wisła", SS "Niemen" and SS "Wart"). Over the period of 7 quarters of a year, the company's fleet transported 346,734 tons of goods (after the tramps were immobilised, in 1933, only 153,734 tons were transported) ${ }^{18}$. In 1934 , the company began to regularly launch its tramp ships: SS “Wilno" (in March), SS "Poznań" (in April), SS “Toruń" (in June) and SS "Katowice" (in December). They made the following trips: "Wilno" (24 trips to: Antwerp, Rotterdam, Amsterdam, Brussels, Dunkirk, Rouen, Oxelösund, Ostend, London, Hull, Cork, Reykjavik, and Burntisland, carrying approx. 50,238 tons of cargo), "Poznań" (on charter as "Arafart") until 19 December 1934, she made 30 voyages in the Baltic Sea and the North Sea, carrying 78,387 tons of goods. At the end of December 1934, she left for West Africa), "Toruń" (made 24 trips to: Rotterdam, Amsterdam, Brussels, Ostend, London, Oxelösund, Gefle, Norrköping, Szczecin, Stockholm,

18 APG OG, SGG, 149/604, Sprawozdanie zarządu S.A. “Żegluga Polska” za rok operacyjny 1932/33, 82 [Report of the Board of "Żegluga Polska" S.A. for the operating year 1932/33, 82]. To compare, the company's liner shipping vessels transported approximately 100,000 tons of general cargo in 1933 alone. The rest of the freight were loads of wood, sugar, grain, scrap, etc. 
Gothenburg, Ystad, Hamburg, and Ghent, transporting 61,042 tons of goods) and "Katowice" (made trips to Amsterdam and Antwerp, carrying 2,690 tons of goods) ${ }^{19}$.

Table 5. Operational results of tramp shipping services in the years 1934-1936

\begin{tabular}{|l|c|c|c|}
\hline \multicolumn{1}{|c|}{ Cargo transported } & 1934 (in tons) & 1935 (in tons) & 1936 (in tons) \\
\hline In export traffic & 117,359 & 260,947 & 249,023 \\
\hline In import traffic & 38,056 & 123,108 & 181,076 \\
\hline Between ports & 39,088 & 8,533 & 18,291 \\
\hline TOTAL & 194,503 & 392,588 & 448,390 \\
\hline
\end{tabular}

Source: APG OG, SGG, 149/605, $10 \mathrm{ff}$.

The year 1935 was finally witnessing a gradual improvement in the tramp shipping market, marked by increases in the employment of tramps and the quantity of transported goods. At that time, transport services were initiated on the route to South America, and a liner service was launched to ports of southern Spain (only for the period of fruit import). SS "Wisła" sailed on the South American route, while the Spanish route was served by three old "Wilno" - type ships (bought in France in 1927). Although they were no longer suitable for use in liner shipping, they made perfect tramps, allowing the carrier to explore the market and collect information for future use in transporting Spanish fruit in the winter season. A further improvement in the overall economic situation on the liner shipping market took place in 1937. At that time, both the quantity of freight transport and the total amount of receipts from freight increased, with all vessels put into service. The ships of “Żegluga Polska” SA made 203 voyages during that year (compared to 173 trips in 1936) ${ }^{20}$. In 1938, tramp shipping again showed a decline in turnover, this time due to a downturn in the general economy and the withdrawal of several ships which were instead deployed in liner services ${ }^{21}$.

Initially, coastal shipping was a loss-making section of the company, but in 1933 there was a clear increase in tourist traffic in Gdynia and on the Hel Peninsula, which resulted in the revival of passenger ship tourism ${ }^{22}$. In 1932-1933, coastal shipping services were maintained on the routes from Gdynia to Hel and Jastarnia, in 1934-1938 from Gdynia and Orłowo Morskie to Hel and Jastarnia, and in 1935-1937 to Sopot.

19 Ibidem, Sprawozdanie zarządu z działalności spótki za rok 1934, 151n [Report of the Board on the company's activities for the year 1934, 151f]. Unfortunately, the register files do not provide the same amount of detail on ship traffic in the years 1932-1933 and 1935-1938.

20 Ibidem, Sprawozdanie zarządu spółki za rok 1937, 113 [Report of the Company Board for the Year 1937, 113].

21 Ibidem, Sprawozdanie zarzadu spółki za rok 1938, 179 [Report of the Company Board for the Year 1937, 179].

22 APG OG, SGG, 149/604, Sprawozdanie zarzadu S.A. “Żegluga Polska” za rok operacyjny 1932/33, 83 [Report of the Board of "Żegluga Polska" S.A. for the operating year 1932/33, 83]. 
These routes were served by SS "Gdynia”, SS “Gdańsk", SS “Jadwiga” and SS "Wanda". The route to Orłowo Morskie was operated by the tugboats "Żubr" (in 1934) and "Łoś" (in 1935-1936). In 1934, the company organised five trips to Bornholm, but in the following years the idea was abandoned. On 1 October 1934, a new service was launched for the first time to provide a winter link between Gdynia and Hel, with the ship "Jadwiga" sailing twice a day between these ports ${ }^{23}$. In the following years, the steamer "Wanda" operated on this route outside the vacation season (in 1935-1938). In 1935, coastal shipping vessels made 32 cruises to Gdańsk, during which tourists visited the port and the city, but this was also only a one-off initiative as the numbers of summer visitors decreased in the following years. In March 1935, “Żegluga Polska” SA took over the shares of "Towarzystwo Turystyki Morskiej" [Maritime Tourism Society], which, in the same year, bought two motorboats in Sweden ("Jaś" and "Małgosia", operated from the summer season of 1936 to 1938) ${ }^{24}$. In 1938, liner services on the routes from Gdynia and Orłowo Morskie to Hel and Jastarnia were maintained (the service to Sopot was suspended), but only three ships were used: "Gdańsk", "Wanda" and "Jadwiga" 25.

As a joint-stock company, "Żegluga Polska” leased four tugboats ("Ursus", "Tur", "Bizon" and "Żubr") from the Maritime Office in Gdynia and operated them from 15 September 1932. From the very start, the company tried to use the boats efficiently to achieve the best possible financial results. In addition to towing ships in the port, they also towed barges between Gdynia and Gdańsk and provided ship rescue services. Additionally, in the summer months, "Zubr" was also employed in transporting tourists visiting the port in Gdynia ${ }^{26}$. In 1934, the company received leased tugboats from the State Treasury as a contribution in kind for FPO shares, and in the autumn of 1934, an additional, fifth vessel of this type was chartered ${ }^{27}$. The fifth tugboat ("Atlas") was purchased in July 1935 in Rotterdam, but the increase in turnover in the towing and rescue department prompted the company to order a new vessel of this type from the Gdańsk Shipyard in November 1935. It was equipped with anti-ice reinforcements as

23 Ibidem, Sprawozdanie zarzadu z działalności spótki za rok 1934, 152 [Report of the Board on the company's activities for the year 1934, 152]. In 1934, the company used its own funds to build a pier in Orłowo Morskie, which allowed the carrier to provide coastline shipping services with a larger vessel. In the same year, the passenger harbour in Gdynia was moved from a wooden pier to Nabrzeże Wilsonowskie [Wilson Quay].

24 APG OG, SGG, 149/605, Sprawozdanie zarzadu S.A. "Żegluga Polska” w Gdyni z działalności za rok operacyjny 1935, 13 [Report of the Board of "Żegluga Polska" S.A. for the operating year 1935, 13]. Ibidem, Sprawozdanie zarzadu za rok 1938, 179n [Report of the Board for the year 1938, 179f]. APG OG, SGG, 149/604, Sprawozdanie zarzadu S.A. “Żegluga Polska” za rok operacyjny 1932/33, 84 [Report of the Board of "Żegluga Polska" S.A. for the operating year 1932/33, 84].

27 Ibidem, Sprawozdanie zarządu z działalności spótki za rok 1934, 153 [Report of the Board on the company's activities for the year 1934, 153]. 
well as rescue and fire-fighting devices ${ }^{28}$. Thus, in 1936 , the company already operated six tugs (including "Tytan" built in Gdańsk). ${ }^{29}$ In December 1938, the tugboat "Łoś" was sold to the Maritime Office in Gdynia (the Office leased the boat from "Żegluga Polska" SA in 1937) ${ }^{30}$.

The first pieces of information on the tonnage of the State Enterprise "Żegluga Polska" in Gdynia, found in the register files, come from April 1930. At that time, the company's fleet consisted of fourteen ships. They included the freighters: SS "Niemen", SS “Wisła”, SS "Warta”, SS “Katowice”, SS “Kraków”, SS "Poznań”, SS “Toruń”, SS “Wilno" and SS "Tczew", and the passenger ships: SS "Gdynia", SS "Gdańsk", SS "Jadwiga", SS "Wanda", and SS "Hanka" 31 . In the first reporting period, i.e. the operating year 1932/1933 (from 1 April 1932 to 31 December 1933), the company’s fleet lost 5,770.3 GRT due to the sinking of "Niemen" and the sale of "Warta" and "Hanka"32. In 1934, the tonnage increased as four new tugs were acquired. Also, in October of that year, two new ships (SS "Hel" and SS "Puck") were ordered to be launched on the routes to Rotterdam and Antwerp. Owing to the increased tonnage, "Żegluga Polska" was able to take two ships off charter ${ }^{33}$. In 1935, the company's fleet was expanded to include

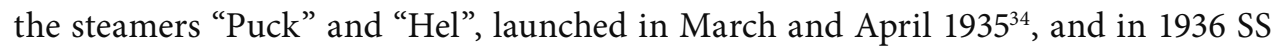
"Lewant" and the sea tug "Tytan" ${ }^{35}$ were added to the fleet's tonnage. In August 1937, the company bought SS "Lechistan", which, together with her sister steamer, "Lewant", was employed on the Levantine line ${ }^{36}$. In 1938, the company's fleet was supplemented by two sister motor ships: MS "Oksywie" and MS "Rozewie". The former was launched in March 1938 to sail on the route to Hamburg, and the latter, a month later, was put on the route to Stockholm. At the beginning of 1938, the company ordered a cargo steamer with a capacity of approx. 1,250 TDW from Gdynia Shipyard (it was to be completed in 1940), and in December 1938, it sold the tugboat "Łos'" to the Maritime Office in Gdynia ${ }^{37}$.

28 operacyjny 1935, 14 [Report of the Board of "Żegluga Polska" S.A. for the operating year 1935, 14].

Ibidem, Sprawozdanie zarządu za rok 1936, 60 [Report of the Board for the Year 1936, 60].

Ibidem, Sprawozdanie zarzadu za rok 1938, 180 [Report of the Board for the Year 1938, 180].

APG OG, SGG, 149/416, 17.

APG OG, SGG, 149/604, Sprawozdanie zarządu S.A. “Żegluga Polska” za rok operacyjny 1932/33, 81 [Report of the Board of "Żegluga Polsk" S.A. for the operating year 1932/33, 81].

Ibidem, Sprawozdanie zarządu z działalności spółki za rok 1934, 154 [Report of the Board on the company's activities for the year 1934, 154].

APG OG, SGG, 149/605, Sprawozdanie zarządu S.A. “Żegluga Polska” w Gdyni z działalności za rok operacyjny 1935, 9 [Report of the Board of "Żegluga Polska” S.A. for the operating year 1935, 9].

Ibidem, Sprawozdanie zarzadu za rok 1936, 57 [Report of the Board for the year 1936, 57].

Ibidem, Sprawozdanie zarządu spótki za rok 1937, 110n [Report of the Company Board for 1937, 110f].

Ibidem, Sprawozdanie zarzadu za rok 1938, 174, 176 [Report of the Board for the year 1938, 174, 176]. 
Initially, the company operated one transshipment warehouse in the port of Gdynia, in which it stored goods transported in liner services. It was located in hangar no. 1 (Nabrzeże Pilotowe [the Pilot Quay]), leased from the Maritime Office, and consisted of a so-called "free trade" section and a transshipment section licensed by the Ministry of Treasury. In 1935, this warehouse was already insufficient, so the company additionally leased from the Maritime Office, "Cukroport" warehouse No. 5 on Nabrzeże Amerykańskie [the American Quay] (in the Free Zone). After another year, both reloading warehouses turned out to be too small, and, therefore, in 1936, the company leased a third warehouse, "Cukroport" No. 3/4 on Nabrzeże Polskie [the Polish Quay]. "Żegluga Polska" SA in the years 1934-1939 belonged to numerous economic organisations: The Polish Shipowners Association in Gdynia, the Polish Ship Managers' Association in Gdynia, the Association of Port Warehouse Owners and Leaseholders in Gdynia, the Gdynia Tourist Propaganda Association in Gdynia, the Association of Cotton Trade Stakeholders in Gdynia, The Baltic \& International Maritime Conference in Copenhagen, and the following Chambers of Commerce (CC): the Polish-Belgian CC in Warsaw, the Polish-Hungarian CC in Warsaw, the Polish-Swedish CC in Stockholm, the Polish-Greek CC in Warsaw, the Polish-Romanian CC in Warsaw, the Polish-Dutch CC in Warsaw, the Polish-Swiss CC in Warsaw, the Polish-Egyptian CC in Warsaw, and the Polish-Palestinian CC in Warsaw.

Before it was transformed into a joint-stock company and became a showcase of the Polish Merchant Navy, Przedsiębiorstwo Państwowe "Żegluga Polska" had been the latter's "experimental station". The story began in the first days of January 1927, when five "Wilno"-type tramp boats arrived from France to Gdynia. Over that year alone, they made 117 voyages, carrying around 300,000 tonnes of exports and imports. "Żegluga Polska" immediately launched coastal shipping services, which contributed to the development of the Polish coastal and tourist traffic. As of 1 January 1929, the Polish merchant fleet consisted of 17 sea-going vessels (excluding tugs and lighters), 14 of which belonged to "Żegluga Polska". When the company was still a state-owned enterprise, apart from tramp and coastal shipping services, it started to run liner services. Initially, the ships sailed on short delivery routes to Estonia and Finland, and later to the Netherlands and Belgium. In the following years, "Żegluga Polska" was systematically developing its own liner shipping network, though its tramp vessels also famously made numerous pioneering voyages. What was extremely important for the development of the Polish Merchant Navy, "Żegluga Polska" facilitated the organisation and establishment of two other shipping companies (in 1929 "Polsko-Brytyjskie Towarzystwo Okrętowe" [Polish-British Shipping Company] SA and, in 1930, "Polsko-Transatlantyckie Towarzystwo Okrętowe" [Polish-Transatlantic Shipping Company] SA), encouraging foreign capital to take an interest in our merchant navy. In 1932, "Żegluga Polska" was transformed into a joint-stock company, thus gaining greater 
freedom of action in the fight against the economic crisis in the global shipping market, from which it emerged victorious. This is best confirmed by its turnover, which continued to grow until the end of 1938, as evidenced by the data presented in this article. The variety of information about "Żegluga Polska" SA contained in the pages of its register files, should encourage researchers to conduct similar analyses of the documents of other shipping, brokerage and freight forwarding companies. They are waiting for scholars in the laboratory of the Gdynia archives.

\section{Bibliography}

\section{Archival materials}

Archiwum Państwowe w Gdańsku Oddział w Gdyni [State Archives in Gdańsk, Gdynia Branch].

Sąd Grodzki w Gdyni [Municipal Court in Gdynia] (APG OG 149/416, 604, 605).

\section{SUMMARY}

English version: Radosław Dolecki, Mark Atkinson

The files of the Companies Register of the Municipal Court in Gdynia kept in the Gdynia Branch of the State Archives in Gdańsk constitute an extremely valuable historical source for research on the history of the maritime economy in the Second Polish Republic. In this article, information from the files was used to describe the circumstances of the establishment, the organisation, the activity, the fleet, and the operational and financial results of Przedsiębiorstwo Państwowe "Żegluga Polska" [State-owned Enterprise "Polish Shipping"] and the joint-stock company of the same name, which in the years 1927-1939 were the showcase of the Polish Merchant Navy. "Żegluga Polska" was established in 1926 under the Stateowned Enterprises Act. The company's development program, adopted by the Administrative Council of "Żegluga Polska" in 1929, provided for the establishment of liner services, without neglecting tramp services. The company's first liner services were to Riga, Tallinn and Helsinki. A vital role in popularising the Polish Merchant Navy was played by the carrier's inconspicuous coastal passenger ships. The advertising slogan "Work on land, rest at sea" quickly attracted crowds of enthusiasts in the country. The register files document in detail the circumstances of transforming Przedsiębiorstwo Państwowe "Żegluga Polska" in Gdynia into a joint-stock company. The transformation was initiated by the Minister of Industry and Trade, Dr. Ferdynand Zarzycki. The company was given a new organisational form because the Government believed that appropriate conditions had been created for the company to be run in cooperation with self-government or private capital. "Żegluga Polska" SA was entered into the Companies Register kept by the Municipal Court in Gdynia on 3 November 1932. At the end of 1938, ten years into its operation, the company boasted eleven transport links with constant cargo flows, connecting Gdynia and Gdańsk with Antwerp, Rotterdam, Hamburg, ports of Italy, Sweden, Finland, Latvia, Estonia, and the Middle East. 
It had the largest fleet out of all the Polish shipping companies, with 16 ships (not counting coastal shipping vessels and tugs) with a total tonnage of 25,073 GRT and was thus a showcase of the Polish Merchant Navy.

\section{Akta rejestrowe przedsiębiorstwa państwowego i spółki akcyjnej “Żegluga Polska” w Gdyni źródłem do dziejów Polskiej Marynarki Handlowej w okresie II RP}

Słowa kluczowe: Gdynia, żegluga, polska marynarka handlowa, okres międzywojenny, archiwum państwowe

\section{STRESZCZENIE}

Niezwykle cennymi źródłami historycznymi do prowadzenia badań nad dziejami gospodarki morskiej w okresie II RP są znajdujące się w zasobie gdyńskiego oddziału Archiwum Państwowego w Gdańsku akta rejestru handlowego Sądu Grodzkiego w Gdyni. Niniejszy artykuł na ich podstawie prezentuje okoliczności powstania, organizację, charakterystykę działalności, tonaż oraz wyniki eksploatacyjne i finansowe Przedsiębiorstwa Państwowego "Żegluga Polska” a także spółki akcyjnej, noszącej tę samą nazwę, będących w 1. 1927-1939 wizytówką Polskiej Marynarki Handlowej. “Żeglugę Polską” powołano do życia w 1926 r. na podstawie ustawy o przedsiębiorstwach państwowych. W programie rozwoju "Żeglugi”, przyjętym przez jej Radę Administracyjną w 1929 r., przewidywano utworzenie linii regularnych, bez zaniedbywania żeglugi nieregularnej. Pierwsze regularne szlaki komunikacyjne przedsiębiorstwa prowadziły do Rygi, Tallinna i Helsinek. Istotną rolę w popularyzacji Polskiej Marynarki Handlowej odegrały niepozorne statki żeglugi przybrzeżnej "Żeglugi Polskiej”. Hasło reklamowe "Pracuj na lądzie, odpoczywaj na morzu”, szybko zjednało sobie w kraju wielkie rzesze entuzjastów. Akta rejestrowe szczegółowo dokumentują okoliczności przekształcenia Przedsiębiorstwa Państwowego “Żegluga Polska” w Gdyni w spółkę akcyjną. Inicjatorem zmian był minister przemysłu i handlu, dr Ferdynand Zarzycki. Przyczyny wyboru nowej formy organizacyjnej tkwiły w przekonaniu Rządu, że stworzone zostały odpowiednie warunki dla współpracy kapitałów samorządowych lub prywatnych w jego dalszym prowadzeniu. “Żeglugę Polską" SA wpisano do rejestru handlowego Sądu Grodzkiego w Gdyni 3 listopada 1932 r. Pod koniec 1938 r., po 10 latach pracy, spółka mogła się pochwalić stałą komunikacją towarową na 11 liniach, łącząc Gdynię i Gdańsk z: Antwerpią, Rotterdamem, Hamburgiem, portami Włoch, Szwecji, Finlandii, Łotwy i Estonii oraz z Bliskim Wschodem. Miała najliczebniejszą flotę z wszystkich polskich towarzystw żeglugowych, dysponując 16 statkami (nie licząc jednostek żeglugi przybrzeżnej i holowników) o łącznym tonażu 25073 BRT i tym samym była wizytówką Polskiej Marynarki Handlowej.

\section{Citation}

Drozd, Jarosław. "Register Files of The State Enterprise and the Joint Stock Company "Żegluga Polska" in Gdynia as a Source in Research on the Polish Merchant Navy under the Second Polish Republic". Studia Maritima XXXIV (2021): 87-101.

DOI: 10.18276/sm.2021.34-04. 